\title{
ZNAČAJ PRAKSE TEMELJENE NA DOKAZIMA U FIZIOTERAPIJI
}

\author{
Azra Tojaga, Vesna Miljanović Damjanović, Josip Šimić \\ Fakultet zdravstvenih studija Sveučilišta u Mostaru
}

Rad je primljen 10.12.2020. Rad je recenziran 17.12.2020. Rad je prihvaćen 19.12.2020.

\section{SAŽETAK}

Fizioterapija je znanstveno utemeljena, predana/obvezana da proširuje, primjenjuje, vrednuje/ evaluira i ocjenjuje dokaze koji podupiru kliničku praksu. Praksa utemeljena na dokazima (EBP) proces je u pet koraka pri čemu kliničari integriraju najbolje istraživanje dokaza s kliničkom stručnošću i preferencijama klijenta. Nedostatak vremena prepoznat je kao značajna prepreka implementaciji prakse temeljene na dokazima u fizioterapiji. Fizioterapeut mora neprekidno ne samo pratiti objavljene znanstvene članke, nego i uspoređivati rezultate provedenih kliničkih istraživanja kojima se ispituje djelotvornost i sigurnost fizioterapijskih postupaka kako bi prakticirao metode koje se danas označavaju terminom "evidence-based physical therapy (EBPT)". Budući su temelj za praksu zasnovanu na dokazima u fizioterapiji obrazovani fizioterapeuti, važno je imati kvalitetne centre za obrazovanje fizioterapeuta.

Ključne riječi: Praksa utemeljena na dokazima, Fiziopterapija, Medicina zasnovana na dokazima, Edukacija

Osoba za razmjenu informacija:

Azra Tojaga, magistar fizioterapije

E-mail: azra. tojaga@gmail.com 


\section{UVOD}

Jedna od profesionalnih uloga fizioterapeuta jeste da u svom kliničkom prosuđivanju trebaju znati pronaći najučinkovitije fizioterapijske postupke temeljene na znanstvenim dokazima. Drugim riječima, trebaju djelovati i kao znanstvenici (1). Fizioterapija je danas neovisna zdravstvena profesija, a fizioterapeute odlikuju tri profesionalne uloge: edukatora, kliničara i istraživača, koje zahtjevaju izgradnju određenih kompetencija(2).

Fizioterapija je znanstveno utemeljena, predana/ obvezana da proširuje, primjenjuje, vrednuje/ evaluira i ocjenjuje dokaze koji podupiru kliničku praksu (3). Provođenje kliničke procjene i interpretacije su njezina suština. Kao znanstveno utemeljena praksa, fizioterapija koristi činjenice, teorije i hipoteze i testira ih na dostupnim podacima. Fizioterapeuti intenzivno istražuju i neprekidno usavršavaju metode procjene i intervencije gotovo svih bolesti i stanja te fizioterapeuti praktičari moraju svakodnevno preispitivati dokaze o djelotvornosti postupaka koje primjenjuju (4). Da bi to bilo moguće, fizioterapeut mora neprekidno ne samo pratiti objavljene znanstvene članke, nego i uspoređivati rezultate provedenih kliničkih istraživanja kojima se ispituje djelotvornost i sigurnost fizioterapijskih postupaka kako bi prakticirao metode koje se danas označavaju terminom "evidence-based physical therapy (EBPT)". Prvo istraživanje u području fizikalne terapije objavljeno je u Sjedinjenim Američkim Državama 1921. u “The PT Review” časopisu (5).

\section{Kvalitetan medicinski dokaz kao središnje mjesto u postupku odlučivanja}

Fizioterapija temeljena na dokazima označava prijelaz tradicionalne paradigme kliničke prakse koja se oslanjala na osnovna znanja o tijeku i prognozi bolesti, intuiciju i kliničko iskustvo, u novu paradigmu u kojoj kvalitetan medicinski dokaz zauzima središnje mjesto u postupku kliničkog odlučivanja fizioterapeuta (6). Praksa utemeljena na dokazima je najvažniji element suvremene fizioterapije, a najboljim dokazima smatraju se randomizirana kontrolirana istraživanja i sustavni pregledi literature(2).

Potrebno je istaknuti dvije glavne razine kada je u pitanju istraživanje prakse utemeljene na dokazima u fizioterapiji. To su istraživanja usmjerena na važnost obrazovanja studenata u području fizioterapije zasnovane na dokazima, te druga razina, koja se odnosi na istraživanje znanja, stavova i prepreka u području primjene prakse utemeljene na dokazima u fizioterapiji. Edukacija o fizioterapiji znatno se promijenila proteklog stoljeća, a pogotovo posljednjih desetljeća.

U istraživanju na području Nizozemske, Sholteni i sur. utvrđuju kako fizioterapeuti, studenti i supervizori pokazuju slabo pozitivan stav prema sudjelovanju u istraživanju. Nastavnici pokazuju najjaču namjeru sudjelovanja $\mathrm{u}$ istraživanju. Studenti su svoje EMB znanje rangirali od nedovoljnog do prosječnog. Štoviše, uglavnom su se koristili udžbenicima i mišljenjem starijih kolega kako bi odgovorili na kliničke probleme, što ne bi trebalo biti uobičajeno ponašanje općeprihvaćene filozofije EBM-a. Ovo otkriće pokazuje dosta loše rezultate jer studenti se uče preuzimati informacije iz kliničkih baza podataka, a ne iz udžbenika (7).

S druge strane u Švedskoj je provedeno istraživanje s 419 fizioterapeuta u primarnoj zdravstvenoj zaštiti. Bila je prisutna značajna stopa odgovora 64 , 7\%. Većina ispitanika imala je pozitivan stav prema EBP-u i smjernicama: 90\% je EBP smatralo potrebnim, a $96 \%$ ih je smatralo važnim. Otprilike dvije trećine izvijestilo je o povjerenju u pronalaženju i korištenju dokaza. Jedna trećina izvijestila je da je upoznata sa smjernicama. Trinaest posto znalo je gdje se mogu pronaći smjernice, a samo $9 \%$ izjavilo je da imaju lak pristup smjernicama za korištenje prakse temeljene na dokazima. Manje od polovice izvijestilo je da se često koristi smjernicama. Najvažnije prepreke korištenju smjernica bili su nedostatak vremena, slaba dostupnost i ograničen pristup smjernicama. Mlada dob i kratko radno iskustvo bili su povezani s pozitivnim stavovima prema EBP-u. Poslijediplomski studij povezan je s većom primjenom EBP-a. Pozitivni stavovi, svijest o smjernicama, razmatranje smjernica za olakšavanje prakse i znanje kako integrirati preferencije pacijenta s upotrebom smjernica bili su povezani s čestom uporabom smjernica. Ključni nalazi ovog istraživanja provedenog bili su da su stavovi prema EBP-u i smjernicama općenito vrlo pozitivni, iako ponašanje koje su izvijestili sami to nije u potpunosti odražavalo, te da svijest i pristup pristup smjernicama i drugi resursi EBP-a bili su ograničeni (8). 


\section{Fizioterapija temeljena na dokazima kao jasan okvir djelovanja u fizioterapiji}

U početku se obrazovanje fizioterapeuta uglavnom temeljilo na vještinama i bilo je klinički fokusirano. Fizioterapija je postala prepoznata na sveučilišnoj razini tek od 1970-ih do 1980-ih godina u zapadnoeuropskim zemljama. Velika Britanija je prednjačila u navedenom i prva u nastavu počela prihvaćati klinički znanstveni okvir (9).

Praksa utemeljena na dokazima (EBP) proces je u pet koraka pri čemu kliničari integriraju najbolje istraživanje dokaza s kliničkom stručnošću i preferencijama klijenta, nudeći odgovarajuću i učinkovitu uslugu. Sve više raste pritisak na fizioterapiju da prihvati praksu utemeljenu na dokazima. Opći cilj medicine utemeljene na dokazima (EBM) je primjena najučinkovitijih metoda za zdravstvo (10). Kako se fizioterapija razvijala tijekom godina to je dovelo do povećanja zahtjeva za korištenje dokaza kao podloge za donošenje kliničkih odluka, jer su na temelju dokaza zasnovane intervencije pokazivale veću učinkovitost (11).

Jako je važno da su metode liječenja koje koriste fizioterapeuti i drugi zdravstveni djelatnicidjelotvorne i zasnovane na dokazima. U području fizioterapije dokazi u vidu znanstvenih članaka brzo se povećavaju kao rezultat opsežnih i mnogobrojnih istraživanja, ali postoji značajan jaz u istraživačkoj praksi i implementacija intervencija utemeljenih na dokazima, a koje su često izazov (12). U svijetu sve veće odgovornosti zdravstvenih djelatnika, praksa utemeljena na dokazima treba biti prihvaćena i biti jasan okvir unutar kojega treba djelovati svaki fizioterapeut. S druge strane, postoji i moralna obveza odlučivanja u okviru prakse utemeljene na dokazima $(13,14)$. Kada su u pitanju načini edukacije fizioterapeuta $u$ području medicine zasnovane na dokazima postoji više njih i teško je procijeniti koji od njih je učinkovitiji. Važno je naglasiti kako postoji nekoliko istraživanja koja su se bavila temom razine znanja fizioterapeuta o sadržaju fizioterapije zasnovane na dokazima. Neki autori smatraju kako bi se sadržaj prakse utemeljene na dokazima u fizioterapiji trebao izučavati i na sveučilištima, ali i kroz cjeloživotno obrazovanje (15-17).

Postoji mnogo istraživanja iz svih područja biomedicinskih i zdravstvenih znanosti koja su javno dostupna, ali često nisu kritički provjerena i ocijenjena. Zbog toga je važno razumijevanje evolucije načina pregleda literature $(18,19)$, nastajanja podataka znanstvenih istraživanja $(20,21)$, upravljanja formalnim kanalima znanstvene komunikacije (22, 23), a kako bi zdravstveni djelatnici mogli primjenjivati znanje utemeljeno na dokazima u svakodnevnom radu.

\section{ZAKLJUČAK}

Nedostatak vremena prepoznat je kaoznačajna prepreka implementaciji prakse temeljene na dokazima u fizioterapiji. Mnogi fizioterapeuti imaju samo ograničen pristup dokazima visoke razine (djelomično zbog ograničenog pristupa bazama podataka koji arhiviraju klinička ispitivanja i preglede ili čak svijesti o tim bazama podataka), što je dovelo do uvjerenja da je malo znanstvenih informacija o učincima intervencije u području fizioterapije. Ostale prepreke se odnose na nemogućnost razumijevanja statistike, nedostatak podrške ustanova u kojima rade, nedostatak resursa i nedostatak interesa.

Kao zaključak možemo istaći i stanje u Bosni i Hercegovini. Ako su temelj prakse zasnovane na dokazima u fizioterapiji obrazovani fizioterapeuti, možemo reći kako trenutno imamo nekoliko Sveučilišta (Mostar, Sarajevo i Banjaluka) na kojima su osnovani studiji fizioterapije. Na dva Sveučilišta se izvodi nastava i na trećem, doktorskom ciklusu studiranja, što jamči najvišu razinu znanja i osigurava budućnost fizioterapije kao posebne grane znanosti.

\section{LITERATURA}

1. Chartered Society of Physiotherapy. Rules of professional conduct, 2nd edn. London, Chartered Society of Physiotherapy. 2007.

2. Josipović P. Važnost formalnog i neformalnog obrazovanja u fizioterapiji. Physiotherapia Croatica, . 2019; 17(1): 145-153.

3. Jewell D. Evidence-Based Physical Therapy Practice In Guide To Evidence-Based Physical Therapy Practice 1 stEd. Jones and Bartlett Publishers, USA, 2008.

4. Jurinić A. Filipec M. Filozofijske pretpostavke i epistemološki temelji teorije fizioterapijske znanosti. Physiotherapia Croatica. 2016: 14(1): 7-14. 
5. Sharma K. Exploration of the History of Physiotherapy. Scientific Research Journal of India. 2012; 1: 1-17.

6. Houser J, Oman KS. Evidence based practice. London: Jones and Bartlett. 2011.

7. Scholten-Peeters GG, Beekman-Evers MS, van Boxel AC, van Hemert S, Paulis WD, van der Wouden JC, Verhagen AP. Attitude, knowledge and behaviour towards evidence-based medicine of physical therapists, students, teachers and supervisors in the Netherlands: a survey. J Eval Clin Pract. 2013; 19(4): 598-606.

8. Bernhardsson S, Johansson K, Nilsen P, Öberg $B$, Larsson ME. Determinants of guideline use in primary care physical therapy: a cross-sectional survey of attitudes, knowledge, and behavior. Phys Ther. 2014; 94(3): 343-54.

9. Perraton L. Embedding Evidence-based Practice Education into aPost-graduate Physiotherapy Program: Eight Years ofpre-Post Course Evaluations. Physiother Res Int. 2017; 22(2). 23-34.

10. Nilsag Y, Lohse G. Evidence-based physiotherapy: A survey of knowledge, behaviour, attitudes and prerequisites. Advances in Physiotherapy

11. Quartey J. Barriers to evidence-based physiotherapy practice for stroke survivors in Ghana South African. Journal of Physiotherapy. S Afr J Physiother. 2018; 74(1): 423.

12. Carlfjord PT. Practitioner experiences from the structured implementationof evidence based practice in primary care physiotherapy: A qualitative study. J Eval Clin Pract. 2019; 25(4): 622-629.

13. Scurlock-Evans L. Evidence-based practice in physiotherapy: a systematic review of barriers, enablers and interventions. Physiotherapy. 2014; 10(3): 208-219.

14. Dannapfel P, Peolsson A, Nilsen P. What supports physiotherapists' use of research in clinical practice? A qualitative study in Sweden. Implement Sci 2013; 8: 31-41.

15. Ruescas-Nicolau, MA, Sanchez-Sanchez, ML, Espi-Lopez, GV. Beliefs, attitudes, knowledge and behaviours towards evidence-based practice of physiotherapy un- dergraduates. Inted2017: 11th International technology, education and development conference. 2017; 2214-2222.

16. Olsen, NR, Bradley, P, Espehaug, B, Nortvedt, MW, Lygren, H, Frisk, B. Impact of a multifaceted and clinically integrated training program in Evidence-Based Practice on knowledge, skills, beliefs and behaviour among. Clinical Instructors in Physiotherapy: A Non-Randomized Controlled Study. Plos One. 2015; 10: 1-17.

17. Stronge M, Cahill M. Self-reported knowledge, attitudes and behaviour towards evidence-based practice of occupational therapy students in Ireland. Occup Ther Int. 2012; 19: 7-16.

18. Tepšić M, Šimić J, Čotić K, Čupić M. Važnost istraživanja i prakse utemeljene na dokazima za sigurnost bolesnika i kvalitetu zdravstvene njege. Zdravstveni glasnik. 2019; 5(2): 95101.

19. Planinić K, Mandić G, Šimić J. Informacijska anksioznost studenata Fakulteta zdravstvenih studija Sveučilišta u Mostaru. Zdravstveni glasnik. 2020; 6(2): 31-41.

20. Krleža-Jerić, K., Gabelica M, Banzi R, Krnić-Martinić M, Pulido B, Mahmić-Kaknjo M, Reverie L, Šimić J, Utrobičić A, Hrgović I. IMPACT Observatory: tracking the evolution of clinical trial data sharing and research integrity. Biochemia Medica. 2016; 26: 308-17.

21. Mahmić-Kaknjo M, Šimić J, Krleža-Jerić K. Setting the IMPACT (IMProve Access to Clinical Trial data) Observatory baseline. Biochemia Medica. 2018; 28(1): 7-15.

22. Utrobičić A, Šimić J, Malički M, Marušić A, Marušić M. Composition of editorial bords and peer review policies of Croatian journals indexed in Web of Science and Scopus. Eur Sci Ed, 2014; 40(2): 31-3.

23. Šimić J, Babić D. Znanstvena komunikacija u biomedicini i zdravstvu. Zdravstveni glasnik. 2018; 2: 68-70. 


\title{
IMPORTANCE OF EVIDENCE BASED PRACTICE IN PHYSIOTHERAPY
}

\author{
Azra Tojaga, Vesna Miljanović Damjanović, Josip Šimić \\ Faculty of Health Studies University of Mostar
}

\begin{abstract}
Physiotherapy is a scientifically based discipline, committed to expansion, application, and evaluation of evidence that support the clinical practice. Evidence-Based Practice (EBP) is a five-step process where clinicians integrate the best research evidence with clinical expertise and client preferences. Lack of time has been recognized as a significant obstacle for the implementation of evidence-based practice in physiotherapy. The physiotherapist must constantly keep track of published scientific articles but also compare the results of clinical trials investigating the effectiveness and safety of physiotherapy procedures in order to implement the methods now referred to as "evidence-based physical therapy (EBPT)". Since the basis for evidence-based practice in physiotherapy are educated physiotherapists, it is important to have quality physiotherapist educational centers.
\end{abstract}

Key words: evidence-based practice; physiotherapy; evidence-based medicine; education

Correspondence:

Azra Tojaga, MPT

E-mail: azra. tojaga@gmail.com 